\title{
Nuno Ramos e os confrontos entre as linguagens: da obra visual à obra literária Cujo (e vice e versa)
} Nuno Ramos and clashes between languages:
visual works from which the literal work (and vice
versa)

Christiane de Faria Pereira Arcuri ${ }^{1}$ 


\section{Resumo}

Neste estudo conferimos à obra literária Cujo (1993), de Nuno Ramos (1960), algumas impressões sobre sua obra visual da mesma década. Como um registro de ateliê, Cujo torna-se um meio para Nuno Ramos expressar-se como artista visual (como num relato diário) e como um narrador (por meio de passagens metafóricas) ao descrever e traduzir o próprio procedimento de elucubração estética e de criação artístico-conceitual. Através da escrita aforismática, Nuno Ramos nos leva a pensar sobre a possivel correspondência entre a narrativa literária e a especificidade matérica concentrada nas composições visuais - mesmo que efêmeras e híbridas. As vozes de Nuno Ramos enfatizam um processo de "transmutação", ou seja, uma "tradução intersemiótica" que contrapõe signos linguísticos a outros tipos de signos, aproximando, dessa maneira, palavras e "coisas" e criando o efeito de narrativas sobre as materialidades do mundo.

Palavras-chave: artes visuais; literatura; signo; corpo; contemporaneidade.

\section{Abstract}

In this study we checked the literary work Cujo (1993), Nuno Ramos (1960), some impressions of his visual work in the same decade. As a studio record, whose becomes a means to Nuno Ramos express himself as a visual artist (as in a daily report) and as a narrator (through metaphorical passages) to describe and translate own aesthetic profundity procedure and artistic and conceptual creation. By aforismática writing, Nuno Ramos leads us to think about the possible match between literary narrative and matter-specific concentrated in the visual compositions - even if ephemeral and hybrid. The voices of Nuno Ramos emphasize a "transmutation" process, ie, a "translation intersemiotic" that opposes linguistic signs to other types of signs, approaching in this way words and "things" and creating the effect of narratives about the material issues of the world.

Keywords: visual arts; literature; sign; body; contemporaneity.

ISSN: 2175-2346

\footnotetext{
${ }^{1}$ Christiane de Faria Pereira Arcuri

Professora Adjunta de Artes Visuais e História da Arte do Instituto de Aplicação - CAP e do Instituto de Artes - IARTS, UERJ.

arcuriarte@gmail.com
} 


\section{Introdução}

Este estudo pretende aproximar o primeiro livro publicado por Nuno Ramos (São Paulo, 1960), Cujo, de 19931, e sua vasta produção visual dessa mesma década. Veremos que no decorrer de três anos consecutivos Nuno Ramos emprega alguns trechos do livro em diferentes oito obras de arte (algumas obras tem os mesmos textos, inclusive), são elas: Breu (1990); Vidrotexto 1 (1991); Vidrotexto 2 (1991); Vidrotexto 3 (1991); Aranha (1991); Canoa (1992); 111 (1992); O pó da cal queima o pó do corpo (1992).

Desse modo entendemos, como objetivos do estudo, que a narrativa de Cujo está associada ao ateliê e revela questões de Nuno Ramos como artista visual: como um diário, o livro traz relatos e descrições das incursões estéticas e conceituais relacionadas ao seu processo artístico. Destaca a relação que estabelece com a efemeridade e a hibridez dos muitos materiais e substâncias que experimenta em suas configurações visuais e que o levam ao intercâmbio que recorre entre as coisas feitas e as palavras ditas. Mammì (1997, p. 201), diz que em Cujo "ao procurar por estruturas linguísticas compatíveis com a autonomia da matéria, [Nuno Ramos] descobre, dentro da linguagem, o elemento matérico, de modo inarticulado". Talvez nessa afirmação esteja a hipótese que nos leva a supor o diálogo entre as linguagens desenvolvidas de modo concomitante por Nuno.

As anotações em Cujo parecem flagrantes das experimentações plásticas ocorridas no ateliê e transcritas de modo fragmentado no decorrer do livro. Nos capítulos que aparentemente se alongam com ideias um tanto reflexivas, porém, intermináveis - o ponto final, muitas vezes, somente surge após algumas páginas de cada conto. Percebe-se que "a prosa não coincide mais com o romance, [...] o fragmento aponta para um ato, um gesto, um mover-se do corpo em direção ao vazio da atenção com a linguagem" (LIMA, 2011, p. 30). Sem dúvida, é possível confrontar a produção literária de Nuno Ramos com suas obras visuais dessa década, em especial pelo modo acumulativo de compor, seja nomeando coisas, seja relacionando-as por meio de elementos artísticos ou mesmo empilhando fragmentos (os literários) na busca de um sentido para a prática plástica.

Nuno Ramos relata, em Cujo, o entendimento do processo visual que desenvolve como artista e a necessidade que o move a "devolver aos objetos fabricados e de uso comum a autonomia do que não tem autor nem utilidade nenhuma" (RAMOS, 1993, p. 59). O que nos parece é que o impulso retórico de Cujo é tão intempestivo quanto tudo o que o autor quer experimentar plasticamente.

Cujo, o mesmo que "aquilo que não se pode dizer o nome"2 aponta, como diz o autor Oliveira (2009, p. 19 e p. 21), "para uma contínua morfologia da vida e de seu entorno, compreendendo objetos e as demais superfícies que em Cujo condensam o nome de 'pele'. O termo 'pele' aqui pode ser ampliado como o revestimento da matéria

\footnotetext{
${ }^{1}$ A primeira edição de Cujo foi impressa com papel-bíblia, especial e transparente, com capa em couché reflex matte, com 150 exemplares numerados e assinados por Nuno Ramos. Há ainda outra edição, também de 1993, publicada pela Editora 34, que atualmente está esgotada. A segunda edição é do ano de 2011 e é a utilizada para este estudo.
}

2 Cujo, conforme o Dicionário Houaiss (1999, p. 473), é um substantivo masculino que pode ser um "sujeito qualquer; o mesmo que dito-cujo", e também "fulano, camarada, cara; pronome relativo - do qual, de quem, de que". 
em sua contínua metamorfose". Em Cujo, Nuno Ramos é um inventor de peles e são nos fragmentos nelas contidos que o artista narrador imprime o gesto de inventar uma pele para tudo. Daí a relação com as suas experimentações plásticas dessa década: testar as superfícies e as texturas de todas as coisas que encontra pelo ateliê: criar cada detalhe.

\section{Os confrontos entre as linguagens visual e literária (e vice-versa)}

Oscilando entre o ensaio plástico e a narrativa metafórica, Nuno Ramos, após tantas incursões plásticas, recorre à palavra de Cujo (que junta tudo) para resumir entre as últimas páginas de sua narrativa: "Costurar. Costurar as próprias cinzas. Costurar as próprias cinzas num corpo novo, frágil, feito de cinzas" (RAMOS, 1993, p. 79). É a suplementaridade do processo visual no literário (e vice-versa).

São esses pedaços do mundo, de mundo e no mundo - as palavras -, que no trabalho visual de Nuno Ramos aparecem numa fulguração de seu uso como a constituição de uma pele. "Uma pele que é também transparência, quando o sentido escorre numa superfície sem fundo e infinita até tentar esmaecer atenuada numa interface oscilante" (LIMA, 2011, p. 30).

Em Cujo, percebe-se que Nuno enumera relatos sobre o processo de elucubração das obras visuais da década de 1990 e não exclusivamente em relação à obra da capa (Fig. 1), intitulada Vidrotexto 1.

Esses relatos disponibilizam, sobretudo, os registros do artista em testar tudo até o ponto de alterar o estado das matérias. O ritmo e o fluxo verbal da narrativa parecem acompanhar as transformações e interferências nas materialidades provocadas pelo artista no ateliê em todos os seus possíveis estados: liquefação, evaporação e solidificação. O artista diz: "Não devo completar tudo. Estar em dia consigo é uma forma de avareza. Preciso encontrar a fração correta de fracasso. Melhor converter a angústia num teatro e o horror num cenário" (RAMOS, 1993, p. 25).

É por meio de duas vozes - entre "conhecimento e revelação" (RAMOS, 1993, p. 9) -, as quais se alternam e se confundem no decorrer da narrativa de Cujo (conforme nos indica Massi ${ }^{3}$ na orelha do livro), que dois diferentes pontos de vista de Nuno Ramos são narrados. Com voz de artista visual, Nuno de forma sistemática, e em primeira pessoa, descreve os questionamentos acerca do processo artístico de configuração de suas obras visuais. E como numa prosa de ateliê, expõe um questionamento: "Havia pouco tempo para mim, pouco tempo para as coisas e por isto tudo parecia tão intenso e cheio de sentido?" (RAMOS, 1993, p. 53).

Uma segunda voz se alterna com a anteriormente citada e a complementa em tom reflexivo - é quando a voz de narrador de Nuno Ramos prevalece (MASSI in RAMOS, 1993, capa). Como autor da narrativa, Nuno descreve e desfia os fragmentos de

\footnotetext{
3 Massi nos indica três vozes a que Nuno Ramos recorre em Cujo. Achamos que duas vozes se alternam, a de artista visual e a de narrador-autor. A terceira voz, reflexiva, a que Massi se refere, parece-nos implícita nas duas vozes em destaque.
} 
memória muitas vezes com o tom de "pequenos anagramas incompreensíveis para os outros [...] reminiscências, ou símbolos, ou histórias pessoais, ou piadas sem graça" (RAMOS, 1993, p. 23). E desabafa mais adiante, dizendo que "nosso corpo é um fole permissivo onde o ar, os ruídos ou os odores (como as bactérias e os pequenos organismos) penetram sem barreira" (RAMOS, 1993, p. 69).

Essas vozes a que Nuno Ramos recorre intermitentemente, a de artista visual mais espontânea, como um desabafo e, a segunda voz - reflexiva, um tanto filosófica -, enfatizam, como destaca Dias (2011, passim), um processo de "transmutação", o que pode ser entendido como uma tradução intersemiótica que confronta signos linguísticos por meio de não linguísticos, aproximando, dessa maneira, palavras e coisas, como efeito de narrativas das materialidades do mundo.

Ao "arrancar a pele das coisas, [e] ver o que havia debaixo" e ao revelar que "por trás de cada pele, portanto, encontra apenas formas degradadas da pele superficial" das "coisas", Nuno procura "devolver a cada pele as outras que perdeu" (RAMOS, 1993, p. 29, p. 31 e p. 67). E em busca da essência dessas coisas, desabafa mais adiante discorrendo, em Cujo: "Cansei de arrancar a pele das coisas". (RAMOS, 1993, p. 39). Nuno revela, ainda, o que the parece mais conveniente:

A troca constante entre as qualidades das peles devolveria ao mundo sua potencialidade original: a de tudo tornar-se a aparência de tudo, sem privilegiar nenhum momento específico. [...] Todas as medidas quantitativas, devido à sucessão inesgotável de possibilidades, ficariam reduzidas a uma única medida. O mesmo com as cores, as palavras, as notas musicais. [...] Assim o todo se faria o tempo todo, numa monotonia variada, sem dar tempo ou nome aos seus pedaços (RAMOS, 1993, p. $67)$.

Deste modo, Nuno propõe uma híbrida correspondência entre os trechos aforismáticos de Cujo e a efemeridade matérica das composições visuais realizadas na mesma década, evidenciando a "Pausa agitada de uma coisa não ser outra", como mesmo diz (RAMOS, 1993, p.41). Num outro trecho do livro, Nuno parece fazer uma constatação: "A matéria deve caminhar disforme, dispersa, irrepetível, portanto moralmente insubstituível, individuada, indiferente a nós, inclusive. No limite, não poderia ser vista, nem sentida, nem ouvida, nem provada" (RAMOS, 1993, p. 15). Todavia, reportamo-nos a Mammì (1997, p. 201), que percebe a agudeza de Nuno como artista visual ao dizer que seu percurso notadamente adquire uma linguagem poética em que cada vocábulo transmite, de modo concomitante, "seja a inércia da matéria que o constitui, seja a invenção, singular e irrepetível, que lhe confere um significado. [...] A descoberta de que o discurso é também matéria".

Com a predominância dessa linguagem aforismática, a própria condição etérea e substitutiva da narrativa literária pode ser traduzida em nome da aquisição de densidades, cores e consistências plásticas produzidas à mesma época por Nuno. Verificamos, contudo, que Cujo anuncia através de uma linguagem metafórica o que Dias (2011, passim) entende como a perspectiva da "tradução poética dos materiais". Como Nuno profere na última estrofe do livro "Cegos para o sol noturno, cegos para o olho que 
lhes resta. Cegos agora do que verão depois" (RAMOS, 1993, p. 81). Em outras palavras, como a expressão da fisicalidade e da densidade dos elementos do mundo ocorre uma tentativa constante, aliás, de Nuno Ramos "em criar 'alfabetos físicos' para expressar a materialidade pelo véu da linguagem, o tempo todo pensada como pele, corpo, opacidade" (DIAS, 2011, passim).

Recorremos ao autor Didi-Huberman no livro O que vemos, o que nos olha (1998) que estuda a experiência visual pautada a partir de duas constatações: a) as imagens são ambivalentes - isso causa inquietação; b) o ato de ver sempre nos abrirá um vazio invencível. O que fazer então diante desse "vazio" que nos inquieta? Didi-Huberman detecta duas respostas: a do leitor que sempre vê alguma coisa além do que se vê num primeiro instante; e a do leitor que procura auxílio através da tautologia, ou melhor, que pretende não ver nada além da imagem, nada além do que é visto. Para o autor, somente uma "experiência visual aurática conseguiria ultrapassar o dilema da crença e da tautologia" (DIDI-HUBERMAN, 1998, p.169).

Para tanto, o autor tem seu foco de estudo nas esculturas minimalistas. O objeto visual, utilizado nas tais referidas obras, é despido de qualquer "ilusionismo", ou seja, os elementos visuais representam esculturas que tendem à simplificação das formas, favorecendo a leitura imediata da percepção dos volumes, cores e texturas - a sensação de se olhar um objeto específico cuja forma perfeitamente fechada torna-se autorreferencial.

Esses mesmos princípios estético-artísticos que o autor atribui às obras dos minimalistas são recorrentes nas relações perceptivas com as obras visuais de Nuno Ramos uma vez que, ambas, colocam os objetos sem "jogos de significações, objetos reduzidos à simples formalidade de sua forma, à simples visibilidade de sua configuração visível, oferecida sem mistério entre a linha e o plano, a superfície e o volume" (DIDI -HUBERMAN, 1998, p. 54).

No entanto, o autor propõe dialetizar a leitura da imagem / obra de arte; problematizar o que vemos. Sugere o autor que, ao se observar uma imagem, haja uma "inquietação" na percepção. As relações com a imagem, num processo dialetizante, pretende que essa inquietação desperte o "entre", ou melhor, o que se vê e o que, de fato, pode ser percebido; a impressão de que alguma outra coisa poderia, de fato, nela estar encerrada - "a suspeita de que algo falta ser visto se impõe doravante no exercício de nosso olhar, agora atento à dimensão literalmente privada, portanto obscura, esvaziada, do objeto" (DIDI-HUBERMAN, 1998, p. 119).

A problematização que Didi-Huberman suscita, pode ser recorrente para a leitura da obra visual de Nuno Ramos: por um lado, há a percepção formal da imagem (os volumes, as cores, as texturas, dentre outros); por outro, um jogo semiótico proveniente das dimensões ocasionadas pelos objetos. Em outras palavras, acreditamos que as obras de Nuno Ramos ocasionam a dialética entre o que pode ser percebido de imediato - as formas, cores, texturas e demais elementos plásticos enquanto si mesmos -, e a estranheza / inquietação visuais causadas pelas composições.

$\mathrm{O}$ ato de ver não é o ato de uma máquina de perceber o real enquanto composto de evidências tautológicas. $\mathrm{O}$ ato de dar a ver não é o ato de dar evidências visíveis a 
pares de olhos que se apoderam unilateralmente do "dom visual" para se satisfazer unilateralmente com ele. Dar a ver é sempre inquietar o ver, em seu ato, em seu sujeito. Ver é sempre uma operação de sujeito, portanto uma operação fendida, inquieta, agitada, aberta. Entre aquele que olha e aquilo que é olhado (DIDI-HUBERMAN, 1998, p. 77).

Adiante, veremos como essa dialética está proferida nas obras visuais de Nuno Ramos.

\section{A visualidade no estilo literário de Cujo}

A começar pelo ano de 1990, a obra de arte chamada Breu tem como parte da composição o trecho da página 9, primeira página do livro Cujo (1993).

No ano seguinte, em 1991, Nuno Ramos produz as obras Vidrotexto 1, Vidrotexto 2 e, ainda, a obra Vidrotexto 3. Essas obras conjugam elementos plásticos a trechos narrados no livro Cujo. Respectivamente, a primeira obra destaca o texto da página 69; a obra Vidrotexto 2 coloca em destaque o texto da página 75 e, a última obra, Vidrotexto 3, condensa os trechos da página 69 (texto também da obra Vidrotexto 1) e da página 71, ambos sobrepostos.

Ainda nesse ano de 1991, outra obra produzida por Nuno Ramos é nomeada como Aranha e apresenta o texto da página 27 de Cujo. Comentaremos cada uma dessas obras no decorrer deste estudo.

No ano seguinte, em 1992, o artista produz mais três obras que trazem outros textos do livro Cujo. São elas: Canoa, com o trecho da página 69, já citado nas obras Vidrotexto 1 e Vidrotexto 3; a obra 111, que foi realizada a partir da invasão do Complexo do Carandiru, em São Paulo, que contém os textos da página 27 (texto que também compõe a obra Aranha) e da página 75 - texto este que também se encontra na obra Vidrotexto 2, do ano anterior.

Outra obra de Nuno produzida nesse ano de 1992 é O pó da cal queima o pó do corpo, título extraído de uma frase de Cujo (na página 73).

\subsection{As obras Vidrotextos (1, 2 e 3) e a obra Canoa}

Inicialmente, reportamo-nos a algumas obras realizadas por Nuno Ramos que apresentam o mesmo trecho da página 69 do livro Cujo4. Referimo-nos às obras Vidrotexto 1 (1991), que é a capa de Cujo e que foi exposta na Galeria Raquel Arnaud no mesmo ano; Vidrotexto 3 (1991), exposta no Museu de Arte Moderna do Rio de Janeiro (em 1992) e que sobrepõe, ao texto da página 69, de Cujo, o trecho da página 71; e Canoa, obra de 1992 que foi realizada no mesmo ano por ocasião da comemoração dos 
70 anos da Semana de Arte Moderna, no Teatro Municipal de São Paulo.

Ao nos depararmos com a obra Vidrotexto $1(30 \mathrm{~cm}$ x $600 \mathrm{~cm}$ x $300 \mathrm{~cm}$ ), exposta no chão da galeria, é possível notar de imediato que o título já menciona algumas das partes que a compõe: percebem-se algumas formas de vidro sobrepostas ao texto de palavras reproduzidas com areia (Fig. 2).

O vidro é o material usado por Nuno Ramos nas esculturas moldadas em folhas de palmeira. Por dentro, o vidro acumula uma certa quantidade de óleo amarelado - o que contrasta com a superfície transparente do vidro. A vaselina, derramada sobre as palavras do texto, é um outro elemento utilizado - o que proporciona um efeito advindo de reflexos (devido à sua transparência) aparentemente propositais, o que parece tumultuar a leitura corrida do texto da obra. Sobre essa questão, Nuno diz em Cujo (1993, p. 33): "A escultura ganhará presença [...] através de sua possibilidade de degradação ou evolução e de sua capacidade de refletir, de receber a aparência de outra superfície". E mais adiante, Nuno complementa: "Quanto mais reflexos, menos propriedades tem um objeto, menos ele se distingue dos demais". A conclusão a que o artista chega "tem sabor de paradoxo: quanto maior o número de reflexos, mais relações um objeto produz, e quanto mais relações, mais semelhante ele se torna" (RAMOS, 1993, p. 51). Isso pode ser constatado por meio do diálogo estabelecido entre os elementos da obra Vidrotexto 1.

Tanto as formas de vidro, como a vaselina - que parece emoldurar as palavras do texto como um verniz -, causam um efeito de transparência sobre o texto descrito. $E$ Nuno Ramos (1993, p. 65) escreve, em Cujo, sobre esse efeito que nos parece causado de modo proposital na obra: "A transparência é uma camada que mal se percebe (a não ser pelos reflexos), mas que cria uma espécie de ambiente. [...] Esta tensão entre as duas imagens, a percebida e a suposta, é que dá interesse à transparência" - remetese à sensação a que DIDI-HUBERMAN (1998, p. 77) profere, como visto anteriormente, entre o que o leitor capta da obra e o que o artista quis transmitir com essa arrumação inusitada dos elementos visuais da obra Vidrotexto 1.

Já na obra Vidrotexto $3(70 \mathrm{~cm}$ x $600 \mathrm{~cm}$ x $400 \mathrm{~cm}$ ) (Fig. 3), além dos materiais apresentados na composição da obra Vidrotexto 1 (vaselina, parafina, vidros), há algumas garrafas. Como pilares, as garrafas sustentam os vidros, nos quais os textos das páginas 69 e 71 de Cujo são transcritos sobrepostos. Os elementos constitutivos da obra são as palavras e os objetos plásticos.

As placas de vidro apresentam-se como suportes para as palavras de Cujo - a obra Vidrotexto propriamente dita. Nota-se que as palavras são transcritas com parafina e funcionam como elemento narrativo-plástico (assim como de modo inverso). As palavras recebem uma camada superficial de óleo, o que propicia reflexo $0^{5}$ por todas as partes da obra. Há, no espaço visual, a pregnância da transparência, tanto a ocasionada pelo óleo como a resultante dos vidros. Assim como se deve destacar a transparência das formas orgânicas dispostas aleatoriamente por toda a configuração da obra.

${ }^{5}$ Em Cujo (1993, p. 65), Nuno descreve que "o reflexo se aloja no interior do

corpo que reflete, como se fosse emitido por ele". 
A obra Vidrotexto 3, além do texto da página 69, apresenta o texto da página 71 (descrito abaixo) sobreposto ao primeiro texto:

\begin{abstract}
A palavra prende em sua boca e seus dois lábios são um só. O cabelo não tem fios. Abre as mãos num gesto lento, murmura seu sussurro e a palavra para. Ela está morta e seu andar de morto é lento. Pede um deus pequeno e sua infância, pede o pergaminho onde a palavra para. Seus lábios são um lábio e seus olhos um só olho, bem grudados. Seu som murmura, seu murmúrio ecoa num sussurro uma palavra morta. Seus pelos não têm fios. Ela imprime em sua pele a casca do tatu, depois o couro dos porcos, peludo, mas seus membros são os mesmos: dedos, seios, narina delicada. Ela imprime o pergaminho nestas peles enquanto se transforma. Está morta agora, a pele tatuada com o couro de outras peles (RAMOS, 1993, p. 71).
\end{abstract}

No ano de 1992, Nuno Ramos realiza outra obra, chamada de Canoa (100 cm x $600 \mathrm{~cm}$ x $400 \mathrm{~cm}$ ) (Fig. 4). Ela apresenta os seguintes materiais: gesso, canoa, cavalete e massa de vidraceiro.

O texto de Cujo (p. 69) também é um elemento que compõe a obra. As palavras do texto foram transcritas com gesso aos pés da escadaria interna do Teatro Municipal de São Paulo. Sobre o texto transcrito no chão, pode-se ver um cavalete que apoia uma canoa (título da obra, inclusive) revestida com massa de vidraceiro e algumas formas orgânicas (moldadas em folhas de palmeira) de gesso.

O "mar" de palavras (do texto de Cujo) assim como os objetos (a canoa, o cavalete e as formas orgânicas) são os elementos que compõem a obra, sobrepostos. Não há a predominância da palavra sobre os objetos, nem muito menos o contrário: a compleição visual é resultante da impressão de que a canoa, assim como os demais objetos, dialoga com a fluidez da narrativa poética de Cujo. Na obra Canoa, o sentido do texto é tão corpóreo quanto os elementos matéricos; a configuração estético-visual estabelecida na leitura fluida entre o texto e os demais elementos da obra é integrada ao ambiente espacial da exposição.

A sobreposição do casco da canoa no cavalete, ambos constituindo objetos estéticos, instiga o diálogo conceitual entre o "mar" de palavras e a plasticidade da obra visual. O movimento (aparentemente aleatório) da textura com massa de vidraceiro na canoa parece contrastar com a acuidade do gesso também utilizado na escritura das letras (nota-se, com o formato de linhas retas) do texto de Cujo.

As obras Vidrotexto 1, Vidrotexto 3 e Canoa exibem o texto da página 69, que é o seguinte:

O som da chuva contra o som das fontes, o contínuo do céu de fora contra o contínuo do chão de dentro. Olho o desfile das vitrines misturadas, a prata enlutada dos seus brilhos e o cortejo fúnebre das mercadorias. Estou bem de passagem, aéreo, sem pisar o peso das minhas solas, de suas bolhas. Estou deitado embora vertical, contra a corrente também aérea dos em-pé caídos, assim dormidos e sem raiz, mortos movidos. Trago os apostos trocados, a parafina no nariz, o óleo nas orelhas e a água por toda parte. Há também o branco súbito em meio ao granito gris e com- 
primido (com buracos moles conquistados), o vidro transparente (com opacidades conquistadas), couros que são pele, peles que são carne, carnes que são osso, ossos brancos e a felicidade (RAMOS, 1993, p. 69).

Aproveitamos para destacar que esse texto enumera pares de palavras com ideias um tanto paradoxais, ou melhor, com significados que remetem ao onírico e ao metafórico, o que não deixa de estar de acordo com a alusão dialética - como vimos com DIDI-HUBERMAN (1998, p. 77) sobre os sentidos tanto plástico como narrativo das composições contemporâneas de Nuno Ramos.

Quando Nuno escreve "apostos trocados", parece fazer referência às ideias e aos elementos divergentes que sobrepõe e conjuga com frequência tanto nessas produções visuais que os citam como nos aforismos de Cujo.

Destacamos do texto da obra alguns pares de palavras citados por Nuno Ramos que vinculam alguns substantivos reentrantes nas histórias que o autor narra (em Cujo) a outros adjetivos esteticamente plásticos que o artista experimenta nas matérias, tais como: "som da chuva"/"som das fontes"; "céu de fora"/"chão de dentro"; "de passagem"/"aéreo"; "deitado"/"embora vertical"; "dormidos"/"sem raiz"; "branco súbito"/"granito gris"; "vidro transparente"/"opacidades"; "couros que são pele"; "peles que são carne"; "carnes que são osso" (RAMOS, 1993, p. 69).

Ao dizer, em Cujo, não saber "como coisas tão díspares se juntam pelo nome" (RAMOS, 1993, p. 71), Nuno torna isso possível nas obras que apresentam o mesmo texto ao conectar o texto (como elemento textual) aos elementos plástico-visuais de modo que, ambos, sejam complementares para o sentido estético e conceitual das obras em estudo. Os pares de palavras compostas e aparentemente sem sentido deste texto, na verdade, reforçam o vínculo que Nuno faz entre os significados intercambiáveis da narrativa metafórica de Cujo e da imagem (a representação visual exemplificada pelas obras Vidrotexto 1 e 3 e, ainda, pela obra Canoa). Lima (2011, p. 28) refere-se a Nuno Ramos como um poeta/artista visual e destaca que, nos últimos anos de sua produção, ele "tem esticado o seu trabalho do suporte de um espaço na geometria escalonada da arquitetura de galerias e instituições até o suporte sofisticado que ainda é o livro, sem perder de vista que um trabalho é também o outro". Em outras palavras, é a suplementaridade da palavra na imagem (e vice-versa).

Reportamo-nos, todavia, à teoria de Didi-Huberman (1998) ao apreciarmos as obras que citam o mesmo texto de Cujo (RAMOS, 1993, p. 69), a saber, as obras Vidrotexto 1, Vidrotexto 3 e Canoa. De início, o texto nas obras parece estar em destaque para o leitor. Ao se deparar com a relação dos "apostos trocados", o leitor inevitavelmente busca as relações existentes entre o sentido das palavras em pares com as formas e os materiais plásticos expostos em cada obra. Automaticamente, o leitor inicia o percurso do olhar sobre os elementos de cada obra e, de forma intensa, procura destacar algumas relações contidas entre os seus elementos.

$\mathrm{Na}$ obra Vidrotexto 1, como exemplo (que merece um destaque maior que as demais obras que apresentam o mesmo texto, porque é a imagem da capa do livro Cujo), destacamos algumas características pertinentes: o texto no chão com areia (que pode, facilmente, ter as palavras desfeitas devido à sua fragilidade); o texto sobreposto por 
formas de vidros com aspecto um tanto orgânico e um pouco deformado; a vaselina sobre o texto, com um aspecto de transparência e leveza sobre as palavras arrumadas com exatidão no chão. Todos esses aspectos descritivos das especificidades da obra Vidrotexto 1 podem ser configurados a partir das dualidades texto-imagem (e vice-versa) e terra-transparência. Todos esses elementos são recorrentes na linguagem visual de uma obra de arte: evidenciam-se aqui as relações com os aspectos claro-escuro, figura-fundo, denso-translúcido, superfície-volume.

Sobre as relações entre substância e conteúdo e entre superfície e forma na obra de arte, Nuno Ramos enfatiza, num trecho de Cujo:

Quando não compomos claramente o contorno de um corpo, o chamamos de disforme, ou amorfo, ainda que possamos medir claramente sua altura ou volume. Uma ou duas dimensões não são suficientes para nos deixar seguros diante do objeto à nossa frente. Precisamos das três. Se não pudermos controlar nenhuma, [...] o amorfo, disforme, monstruoso, ganha o contorno invertido do sublime (RAMOS, 1993, p. 43).

Dessa forma, supomos que, ao integrar os objetos e os elementos plásticos às ideias conceitualmente divergentes e aparentemente discrepantes dos seus pares de palavras (os "apostos trocados"), Nuno Ramos propicia uma leitura que vai além da restrita descrição de seus elementos (o textual e os visuais) e que deixa à mostra a necessidade de uma articulação entre o sentido do texto descritivo e os elementos visuais aplicados ao texto pelo artista autor (e vice-versa).

Assim como as obras minimalistas postas em destaque por Didi-Huberman, Nuno Ramos, ao justapor elementos visuais (e também esteticamente conceituais) sobre o corpo textual, provoca-nos uma dialética do olhar, ou seja, o jogo eloquente que só uma obra de arte possibilita entre a sua própria aura e a correspondência com seu leitor. A leitura de cada obra vai além da estrita descrição e enumeração dos aspectos da linguagem formal dos seus elementos, uma vez que esses elementos complementam estética e conceitualmente o sentido das palavras do texto.

Da mesma forma como Didi-Huberman (1988) defende que a "antropologia da forma" deve ser uma experiência visual aurática inquietante, as obras em estudo, na condição de poéticas da contemporaneidade, proporcionam uma leitura dialética: fundamentalmente ambígua e plural, a descrição do texto estende esses mesmos atributos à suplementaridade dos elementos visuais. Nesse sentido, essas obras de Nuno possibilitam uma leitura pela qual "não há que escolher entre o que vemos e o que nos olha. Há apenas que se inquietar com o entre. Há apenas que tentar dialetizar" (DIDI -HUBERMAN, 1998, p. 71). E Nuno parece comentar essa questão quando diz:

Há algo de espelhado, de invisível portanto, em tudo o que vemos: aquilo que é refletido, a luz que abre os objetos ao olhar e às relações com os outros objetos. Se todas as coisas refletissem como espelhos, viveríamos num mundo de relações ininterruptas: tudo remeteria a tudo, como quando pomos um espelho em frente ao outro (mas como seria monótono!). A identidade de um objeto depende antes de 
mais nada de sua opacidade. É ela que o separa dos demais e guarda para si suas propriedades. (RAMOS, 1993, p. 49).

Ao mesclar o texto literário e os materiais plásticos, essas obras em estudo tornam-se imagens-dialéticas, o que pode provocar no leitor um inicial estranhamento, um entremeio nas significações do olhar interpretativo. O que ocorre é que a composição do texto narrativo com elementos que adquirem um caráter plasticamente conceitual possibilita que estes últimos elementos (também estéticos) funcionem como objetos à medida que são traduzidos pelos signos do texto em cada obra. Essa dupla distância entre o que é visto e o que o leitor percebe coloca os elementos da obra agindo como "presenças", como "corpos", ou seja, como "objetos de conhecimento e de visualidade; são coisas a tocar; volumes orgânicos; talvez o próprio olho". (DIDI-HUBERMAN, 1998, 30). Nuno Ramos, ao falar do seu processo artístico em Cujo, reforça essa questão:

\begin{abstract}
Agora eu tinha um pedaço de algo. Precisava erguer aquilo, dar forma, mas não sabia como determinar essa forma. Não sei por que qualquer escolha parecia tão falsa. Queria que ela aparecesse por si só. Então juntei simplesmente vários pedaços e costurei um tapete disforme. Mas os contornos desse tapete pareciam sempre escolhidos cuidadosamente. Acabei destruindo tudo. Não consigo passar da pele (RAMOS, 1993, p. 19).
\end{abstract}

Portanto, não devemos compreender essas obras-imagens como sendo apenas aquilo que elas mostram, o seu conteúdo visível, pois uma imagem é principalmente aquilo que os sujeitos veem ao estabelecerem uma relação com elas. Tratar a imagem como mera aparência seria simplificar demasiadamente a questão, é subjugá-la à coisa representada, reduzi-la meramente à sua visibilidade, assim como tratá-la como uma realidade autônoma é ignorar sua relação com quem a olha. Assim, torna-se relevante associar a produção visual de Nuno Ramos, exemplificada pelas obras Vidrotexto 1, Vidrotexto 3 e Canoa, à narrativa de Cujo. Mammì (1997, p. 201) conjuga essas ideias quando diz que é significativa a semelhança da obra de Nuno Ramos a um organismo, como "garantia de uma mediação entre nós e os objetos inanimados".

No entanto, torna-se oportuno nos remetermos a Jakobson (1969), que define "tradução intersemiótica" como "transmutação" de signos, do sistema verbal para outro sistema, de diferente natureza - como dito anteriormente por Dias (2011, passim). Em se tratando das obras estudadas, enfatizamos a intrínseca relação do texto literário em cada obra com os materiais plásticos. Um modelo de tradução intersemiótica para Jakobson seria o que se relaciona à noção peirceana de semiose, ou seja, a relação entre as "hierarquias descritivas" dos elementos constitutivos, a saber, o signo/o objeto/o interpretante-leitor de uma tradução. Nas obras em foco, existe a relação de interdependência entre a narrativa textual e os elementos visuais, ambos agindo como presenças a serem relacionadas pelo espectador-leitor.

Constata-se, todavia, que os elementos plástico-estéticos empregados nas obras Vidrotexto 1 (a areia, o vidro, a vaselina e o óleo), Vidrotexto 3 (além dos elementos da 
obra anterior, as garrafas) e Canoa (gesso, massa de vidraceiro, além da canoa e do cavalete) funcionam como signos visuais, assim como o texto funciona como signo literário na interpretação e leitura da obra. Com a tradução intersemiótica, para que ocorra a transmutação de signos, as relações de valores entre signo-objeto-interpretante tornam-se imprescindíveis, assim como os meios empregados e as linguagens onde são aplicados. Em Cujo, a narrativa utilizada por Nuno Ramos corresponde à forma e ao caráter de tradução da obra visual - a transmutação, portanto, pode ser entendida a partir das relações de semelhanças e proximidades entre signo-objeto-interpretante/ leitor.

Em outras palavras, um signo é qualquer "coisa" que determina que alguma outra "coisa" estabeleça relação com o seu objeto de origem. Ou seja, a semiose ocorre quando existe a relação entre o referente e o seu referencial - ou, visto de outra forma, entre o objeto e o signo correspondente ou, ainda, entre o objeto e o seu interpretante -leitor da obra. Do mesmo modo que o objeto pode estabelecer uma relação sígnica, o interpretante torna-se o extremo na relação de interdependência entre os signos e os objetos (textuais e visuais). A esse propósito, Nunes (2011, p. 18) diz que as obras representativas da atualidade têm "a palavra [que] revela imagens, desvela artifícios, permite aproximações, substituições, ambiguidades, analogias, transposições, condensações [e] reversões".

Os intervalos entre a voz de artista visual e o tom de narrador reflexivo a que Nuno recorre na escrita literária potencializa os entremeios da leitura da obra visual e de seus significados. Tassinari (1997, p. 22) enfatiza que a justaposição de elementos nas obras de Nuno estão de acordo com a escrita aforismática de Cujo. Pode-se afirmar que Nuno, em Cujo (1993, p. 33), imprime um ato literário-plástico (e também ao contrário) de comentário do mundo ("Aflição diante das coisas que duram. Para quem elas duram?") - e não somente de experiência visual: "É a matéria que se expressa na obra, mostrando-se em sua unicidade. Essa unicidade porém não é tão diferente da unicidade das palavras, dos gestos, das operações e dos discursos. O artista também é matéria" (MAMMì, 1997, p. 202).

De fato, o que Nuno diz em Cujo é o que se vê nessas obras visuais, e vice-versa:

O descompasso entre o enchimento e a superfície, entre os tendões e a pele é fundamental. Quanto menor o vínculo entre estes dois momentos, maior a diferença entre as partes. A forma deve esconder sua origem, de modo que pareça ilógica e arbitrária. Cada parte do trabalho entrará por isso em choque com as demais. A soma destes choques, no entanto, pode ter um resultado harmônico, pois a imantação do todo, o fascínio difuso, a beleza enfim do trabalho será sempre a parte mais importante de sua autonomia, de sua maioridade, de sua ambiguidade e vida própria. Esta beleza do todo receberá todavia a aparência fracionada de suas partes, adquirindo uma duração. Será preciso percorrer o que não se junta antes de conciliá-lo; talvez seja preciso percorrê-lo sem poder conciliá-lo, e neste caso a vida cretina terá vencido. Esta duração é o tempo humano, corpóreo, fraco e decaído, mas que catapulta o olhar para o todo sem tempo, vermelho, dourado, em expansão sem cansaço. (RAMOS, 1993, p. 63). 
Reportar-nos-emos, a partir daqui, à obra Vidrotexto 2 (1991), a qual, por sua vez, faz parte da sequência de obras com o mesmo nome (Fig. 5).

Essa obra apresenta o texto da página 75 de Cujo:

Quando o próximo peixe saltar vou avisá-lo: cuidado com a garça. Não queremos que se machuque, nós que amamos as coisas paradas. Estamos cansados de bicos de garça. A árvore que cai deve ser morta antes. Vamos lavar a pele de um morto. Vamos nos aquecer sob esta pele malcheirosa. Quero estudá-la à noite, ler seu mapa (coisas-mapa para homens cegos). Estes pequenos urros devem morrer antes, estas pequenas doses diárias. Estas madonas mortas devem dar seu leite de volta às vacas. Devem colocá-lo lá, já escuro, dentro dos ubres e os ubres dentro das vacas (RAMOS, 1993, p. 75).

A obra Vidrotexto 2 apresenta os seguintes materiais: espelho, parafina e resina sobre madeira. A madeira (com seis painéis) é o suporte do texto; esses painéis nos remetem à aparência de portas que, juntas/lado a lado, formam um grande painel retangular com dimensões entre três e seis metros.

As palavras do texto estão escritas nesse painel com resina e são cobertas no suporte de madeira com camadas alternadas de parafina e pedaços de espelhos colocados aleatoriamente. Podemos notar, sobre o texto, a incidência de efeitos de transparência e de impermeabilização causados pela resina e pela parafina. Já os pedaços de espelho propiciam ao leitor que perceba o reflexo de sua própria imagem - o que o leva a interagir mais diretamente com a obra. Podemos afirmar que, assim, a superfície da obra espelha a unidade entre a matéria e o texto de Cujo ${ }^{6}$.

Outro aspecto que destacamos é a regularidade do formato das letras do texto, que parece se alternar com a irregularidade das camadas de transparência obtidas pela vaselina e pelos cacos de espelho. A impressão entre o texto (o fundo) e as camadas de vaselina se alterna na compleição física da obra, e a leitura do texto não chega a ser interrompida pelos elementos matéricos.

Deve-se destacar ainda que, diferentemente das demais obras dessa série (os Vidrotextos 1 e 3), o suporte do texto em Vidrotexto 2 está na vertical, apoiado na parede da sala de exposição. Assim, a leitura da obra pode ser realizada no plano bidimensional, o que aproxima a obra Vidrotexto 2 da disposição visual das demais obras do início da produção artística de Nuno Ramos, os Quadros sem títulos.

\subsection{As obras Breu, Aranha e O pó da cal queima o pó do corpo}

As obras Breu, Aranha e O pó da cal queima o pó do corpo também apresentam trechos do livro Cujo?.

\footnotetext{
6 Nuno, em Cujo (p. 51), diz que há "três modos de invisibilidade: a) tudo refletir (nunca vemos os próprios espelhos, somente as imagens refletidas); b) nada refletir (objetos absolutamente opacos, como os buracos negros, que absorvem inteiramente o sinal luminoso); c) transparência".
}

7 Neste estudo, a sequência estabelecida para a descrição das obras refere-se à ordem cronológica em que foram produzidas. 
Iniciamos com a obra Breu, de 1990, que foi exposta no Centro Cultural São Paulo no mesmo ano (Fig. 6).

O texto da página 9 de Cujo foi escrito com carvão sobre o chão e coberto por uma película de breu, verniz industrial de cor escura. O trecho de Cujo é o seguinte:

\begin{abstract}
Pus todos juntos: água, alga, lama, numa poça vertical como uma escultura, costurada por seu próprio peso. Pedaços do mundo (palavras principalmente) refletiamse ali e a cor dourada desses reflexos dava uma impressão intocada da realidade. [...] Seria preciso, então, que os materiais se transformassem uns nos outros ininterruptamente e, o que é mais difícil, encontrar um nome para este material proteico, um nome que tivesse as mesmas propriedades dele (RAMOS, 1993, p. 9).
\end{abstract}

A obra Breu, vale destacar, é a primeira, dentre as demais obras, em que Nuno Ramos destaca um texto do livro Cujo. Esse texto é o primeiro trecho do livro (está na primeira página) e mostra-nos o propósito que o artista tem em descrever a narrativa com uma relação biunívoca à sua produção visual.

Assim como nas obras anteriormente citadas, as palavras do texto parecem "petrificadas" pela camada que as torna como que emolduradas com uma substância transparente, o breu, que causa um efeito de impermeabilização no texto. Nela, o verniz breu é utilizado com propriedade e função similares às das demais substâncias usadas nas obras já descritas neste trabalho, isto é, o óleo, a parafina, o vidro, a vaselina e a resina.

Exposta (e composta) na horizontalidade do chão do espaço da exposição, a obra traz a palavra com efeitos matérico e plástico. A narrativa do relato de Cujo (p. 9) pode ser percebida como um elemento estético, em destaque por meio do efeito de transparência causado pelo breu sobre as palavras escritas com carvão.

Outra obra que também apresenta um trecho de Cujo é Aranha $(300 \mathrm{~cm}$ x $600 \mathrm{~cm}$ x 300 cm), de 1991, que foi exposta no Galpão Embra, Belo Horizonte, no mesmo ano. Os materiais empregados são: vaselina, óleo, pelúcia, algodão e tule (Fig. 7).

A forma que remete ao corpo de uma aranha é composta de pelúcia e algodão, características matéricas discrepantes da imagem que (ocasionalmente) nos remete a uma aranha; esses elementos são recobertos com tule (um tecido leve e transparente) e por uma camada de óleo.

O texto de Cujo é transcrito inicialmente na parede e segue, continuamente, pelo chão do espaço da exposição. O texto, assim como nas obras anteriormente estudadas, é coberto com óleo e vaselina:

Eu quis ver mas não o vi. Eu quis ter mas não o tive. Eu quis. Eu quis o deus mas não o tive. Eu quis o homem, o filho, o primeiro bicho mas não os pude ver. Estava deitado, desperto. Estava desde o início. Quis me mover mas não me movi. Eu quis. Estava debruçado, morto desde o início. A grama alta quase não me deixava ver. Estava morto desde o comecinho. Eu quis o medo mas não o pude ter. Estava deitado, debruçado bem morto. Quis ver o primeiro bicho e a raiz da primeira planta. A grama alta não me deixava ver. Quis ficar acordado mas dormi. Estava deitado e a 
grama alta não me deixava ver. Os olhos esbugalhados quase morriam pela última vez. Estava ali desde o comecinho. Eu quis o medo mas não o pude ter. Quis o sono, a arca, algum algarismo romano. Quis o homem, mas não este aqui. Quis um deus, mas não este aqui. Ouvi os mil ruídos sem saber do quê. Estava debruçado sobre a grama. Quis virar o corpo e olhar o céu mas não este aqui. Quis olhar a carne desde o comecinho, por trás da pele mas não demasiado profundo. Quis olhar a carne e a raiz da primeira planta (esta só tinha caule). Quis o medo mas não disso aí. Quis dizer: disso aí. Quis virar o corpo mas sem me mexer. Estava morto desde a primeira planta. Estava morto bem morto desde o comecinho da primeira planta. Era um fóssil da primeira planta mas não esta planta aí. Quis dizer: esta planta aí. Quis olhar, olhar, olhar isto aqui. Estava debruçado sobre a grama alta sem me mexer. Quis virar o corpo e ver o céu mas não este aqui. Estava bem morto e quis dizer isto aqui (RAMOS, 1993, p. 27).

A obra chamada O pó da cal queima o pó do corpo $(200 \mathrm{~cm}$ x $500 \mathrm{~cm}$ x $200 \mathrm{~cm}$ ), de 1992, também apresenta um texto do livro Cujo (p. 73). Foi exposta na exposição coletiva Poética, no Gabinete de Arte Raquel Arnaud, no mesmo ano. Como materiais, apresenta seixos, vaselina, breu, arame e vidros (Fig. 8).

A composição visual dessa obra apresenta seis pedras espalhadas pelo chão da galeria, nas quais estão escritas as nove palavras que compõem seu título. As palavras foram transcritas com vaselina e recobertas com breu ${ }^{8}$. De cada uma dessas pedrasseixos, parte uma haste construída com vidros soprados; as hastes têm tamanho em torno de dois metros e inclinam-se para o teto do espaço da exposição. Percebe-se que Nuno faz referência a essa obra quando diz, em Cujo:

Não sei como coisas tão díspares se juntam pelo nome. Podemos pôr as palavras juntas [...]. Uma pedra é tão distante de outra pedra, vizinha, mas nós dizemos pedra, nós, bichos de carne, que nem um corpo duro temos, só esta bolha fraca e molhada. [...] A pedra de nossa lápide e a cal que nos termina, estas também são coisas. Mas cuidado, a palavra é que junta tudo (RAMOS, 1993, p. 79).

\subsection{A obra 111}

A obra conhecida como 111 foi realizada por Nuno Ramos em memória dos 111 presos mortos em 2 de outubro de 1992 durante a invasão da Casa de Detenção de São Paulo pela Polícia Militar (Fig. 9).

A exposição teve três montagens: a primeira em Porto Alegre, um mês após a invasão; a segunda, no Gabinete de Arte Raquel Arnaud, em junho de 1993; e a terceira, na Bienal Brasil Século XX, em 1994.

A exposição foi composta por 111 paralelepípedos recobertos com asfalto e breu.

8 Em Cujo (p. 11), Nuno diz: "Pôr um nome dentro de uma pedra não faz sen-

tido, pois ela já tem este nome, pedra". 
Sobre cada um deles estava depositado o nome de um dos mortos - impresso em chumbo num clichê de linotipia - copiado de uma notícia de jornal sobre o massacre. A notícia foi mergulhada em breu. Nas paredes, com letras de vaselina, havia o seguinte texto de Cujo (texto este também citado na obra Aranha, de 1991):

Eu quis ver mas não o vi. Eu quis ter mas não o tive. Eu quis. Eu quis o deus mas não o tive. Eu quis o homem, o filho, o primeiro bicho mas não os pude ver. Estava deitado, desperto. Estava desde o início. Quis me mover mas não me movi. Eu quis. Estava debruçado, morto desde o início. A grama alta quase não me deixava ver. Estava morto desde o comecinho. Eu quis o medo mas não o pude ter. Estava deitado, debruçado bem morto. Quis ver o primeiro bicho e a raiz da primeira planta. A grama alta não me deixava ver. Quis ficar acordado mas dormi. Estava deitado e a grama alta não me deixava ver. Os olhos esbugalhados quase morriam pela última vez. Estava ali desde o comecinho. Eu quis o medo mas não o pude ter. Quis o sono, a arca, algum algarismo romano. Quis o homem, mas não este aqui. Quis um deus, mas não este aqui. Ouvi os mil ruídos sem saber do quê. Estava debruçado sobre a grama. Quis virar o corpo e olhar o céu mas não este aqui. Quis olhar a carne desde o comecinho, por trás da pele mas não demasiado profundo. Quis o medo mas não disso aí. Quis dizer: disso aí. Quis virar o corpo mas sem me mexer. Estava morto desde a primeira planta. Estava morto bem morto desde o comecinho da primeira planta. Era um fóssil da primeira planta mas não esta planta aí. Quis dizer: esta planta aí. Quis olhar, olhar, olhar isto aqui. Estava debruçado sobre a grama alta sem me mexer. Quis virar o corpo e ver o céu mas não este aqui. Estava bem morto e quis dizer isto aqui (RAMOS, 1993, p. 27-29).

Havia caixinhas na parede, com diversos revestimentos e textos retirados de Cujo; três peças feitas de paralelepípedos, barro cru, vaselina, cinzas de páginas queimadas da Bíblia e folhas de ouro; um elemento fino, em cruz, disposto no meio da sala e feito com a soma dos nomes dos mortos impressos em clichês de linotipia - 55 nomes num dos braços e 56 no outro. Havia também fotos aéreas na parede que foram obtidas por satélite na data e horário da invasão.

Nas duas últimas montagens, escrito sobre um tule - que dividia os dois ambientes da terceira exposição e fechava o segundo ambiente da segunda exposição -, havia outro trecho de Cujo, que, inclusive, é citado na obra Vidrotexto 2 (1991):

Quando o próximo peixe saltar vou avisá-lo: cuidado com a garça. Não queremos que se machuque, nós que amamos as coisas paradas. Estamos cansados de bicos de garça. A árvore que cai deve ser morta antes. Vamos lavar a pele de um morto. Vamos nos aquecer sob esta pele malcheirosa. Quero estudá-la à noite, ler seu mapa (coisas-mapa para homens cegos). Estes pequenos urros devem morrer antes, estas pequenas doses diárias. Estas madonas mortas devem dar seu leite de volta às vacas. Devem colocá-lo lá, já escuro, dentro dos ubres e os ubres dentro das vacas (RAMOS, 1993, p. 75). 
Para a montagem no Gabinete de Arte foi produzido um catálogo que continha, além de reproduções da escultura-instalação, um trabalho gráfico criado especialmente para ela, que utilizava fotos aéreas, vidros soprados e fumaça colorida e branca. O catálogo terminava com um comentário de Nuno Ramos à exposição:

Esta exposição, [...] mais do que a própria invasão, no entanto, forma as fotos dos mortos, expostas assim tranquilamente em qualquer banca de jornal, em plena luz do dia, que de fato me impressionaram. Havia uma espécie de naturalidade naquelas imagens, anônimas, algo coletivas, como se pertencessem a uma sequência, anterior e posterior ao acontecimento. Nada parecia terminar, nem começar, ali.

Acho que minha primeira intenção foi construir pequenas "caixas de memória", utilizando o que havia chegado até mim: os nomes dos mortos e seus macabros instantes de publicidade (as notícias de jornal). Pintei com asfalto frio 111 paralelepípedos, ou pequenas lajes, e os recobri com breu. Depositei sobre eles os nomes de cada um dos mortos, impressos em chumbo (linotipia), o xerox de uma notícia de jornal sobre o massacre mergulhada, 'mineralizada', em breu e a cinza de um salmo, queimando em sua homenagem uma página da Bíblia. Escrevi sobre a parede, com letras quase invisíveis de vaselina, um texto meu, anterior ao acontecimento, mas que me parece parente próximo do resto da exposição. As caixinhas sobre a parede, com revestimentos diversos, contêm cinzas de páginas da Bíblia e textos de minha autoria impressos em ácido sobre seus vidros. As 3 múmias são feitas de paralelepípedos, barro cru, vaselina, cinzas de páginas da Bíblia e folhas de ouro. O elemento fino e vertical que aparece em algumas fotos é uma espécie de cruz molenga, feita com a soma dos nomes dos mortos impressos em linotipia.

Esta parte do trabalho foi exposta em novembro de 1992, um mês após a invasão, na Casa de Cultura Mário Quintana, em Porto Alegre. Criei agora, para esta $2^{\mathrm{a}}$ versão no Gabinete de Arte Raquel Arnaud, um complemento aéreo, algo celeste. A partir de uma imagem de satélite do dia e da hora exatos da invasão do presídio (16:30hs de 2 de outubro de 1992), realizei um trabalho com ampliações gigantescas de fotos de nuvens, com vidro e com fumaça, procurando dar leveza, redenção talvez, à quase tumba dessas pedras, múmias, cinzas, cruzes. Agora, organizada em duas partes, entre a pedra e o ar, a terra e as nuvens, a exposição me parece mais completa (RAMOS, 1993, p. 2).

As montagens que se seguiram, nos anos subsequentes, foram sendo complementadas por Nuno Ramos - o artista montou, em público, à época do acontecimento, a primeira versão da exposição; a segunda exposição já pôde ter outros seis meses de elaboração. De acordo com os comentários de Tassinari (1997, p. 192), a preocupação de Nuno Ramos parecia ser a de não exagerar nas tintas - "toda referência às imagens da tragédia, estampadas sensacionalmente nos jornais na primeira semana de outubro, foram praticamente abolidas". A obra 111 aglomera uma vasta gama de elementos que pareciam buscar um novo caminho de investigações arbitrárias, ou melhor, assim como havia fragmentos da morte, havia também pedaços da vida. "Sentia-se uma certa profusão obscura de ausência e sufocamento através do ambiente esbranquiçado 
da exposição. [...] A obra impressiona pelo seu aspecto grotesco". (TASSINARI, 1997, p. 192).

A escultura em barro cru logo na entrada da exposição, que Nuno chamou de múmia, tinha aspecto de um sarcófago. Os paralelepípedos espalhados pelo ambiente foram dispostos ao acaso, o que remetia a restos de uma barricada após a luta nas ruas, e davam, ao mesmo tempo, movimento à cena, como uma revolta. Os paralelepípedos representando os 111 mortos pareciam "repousar", assim como os que foram representados pela chacina; e a cor do breu causava uma impressão de chama acesa.

Tassinari (1997, p. 192) diz que Nuno pareceu ser "poeticamente motivado" ao evocar os mortos, assim como fora costume na Grécia. Quando o corpo de um ente querido, conta o autor, não podia ser encontrado após um acidente natural ou uma batalha, os gregos dessa época moldavam em pedra um duplo do desaparecido. Este tinha a função de "segurar" seu corpo à terra. A alma do desaparecido, a partir de então, "deixava de errar" entre o mundo dos vivos e o dos mortos; não viria mais atormentar os primeiros, e nisso cessava também o seu tormento. Importante para a cerimônia, porém, era que o duplo do corpo não imitasse as suas feições e viesse a ter comunicação pela imagem, desse modo, com sua alma. Como nas pedras da obra 111, tais duplos foram feitos com pedras retangulares, pois tratava-se de libertar a alma e não de presentificá-la.

De uma segunda maneira, Nuno Ramos retoma a cerimônia grega quando coloca o nome do morto diante do duplo, como era costume na Grécia, e repete o nome do falecido por três vezes. A tríplice repetição do número 111 nos parece um resgate que remete ao mesmo ritual. Cada lápide da obra 111 foi por três vezes trabalhada: primeiro, pela presença do nome em linotipia, o que nos leva a lê-lo pelo avesso; segundo, pelo pedaço de jornal com fragmentos das notícias da chacina; e, por último, por folhas queimadas de uma Bíblia.

Mais abaixo, a obra continha alguns fragmentos do livro sagrado. O texto em vaselina escrito por Nuno na parede branca parecia uma versão em negativo do texto bíblico queimado. "A Bíblia consumida em seu próprio fogo, seria, quem sabe, a alegoria de um mundo já sem espírito, ou do qual o espírito se ausentou? A obra, apesar do seu esquema plástico evidente, nos convida a interpretações alegóricas", comenta Tassinari (1997, p. 192).

Ainda para o mesmo autor (1997, p. 192), os trechos de Cujo escritos nas paredes laterais da exposição falavam de temas como a criação artística, os preceitos morais, as observações aparentemente científicas e os fatos cotidianos. O livro tem trechos oníricos, outros realistas; alguns são dissertativos. Cujo (como já vimos) é um pronome relativo, a denominação de uma pessoa qualquer e/ou o nome de uma entidade que não quer se nomear. Reúne, no entanto, três acepções que fazem com que Nuno Ramos retenha na palavra uma conotação um tanto contraditória: "Seu poder de substituição é tamanho que ela chega mesmo a poder nomear o inominável. Um conflito irremediável entre as palavras e as coisas vem se instalar. O mundo e seu sentido parecem escapar a uma denominação completa e individualizadora" (TASSINARI, 1997, p. 193).

Vimos, nas obras relacionadas neste estudo, que a quantidade de elementos a a diversidade de materiais arranjam-se barrocamente ao eixo verbal de Cujo. Conjugan- 
do as cinzas de textos sagrados a extratos literários do próprio artista, à gravação dos nomes dos mortos e a restos de notícias de jornal, o caráter da obra aprimora a sua recorrência minimalista, acomodando os componentes sacrificiais de ritualização da dor - o que faz Nuno dizer, ao final de sua descrição da obra:

\footnotetext{
Acho que meu trabalho, tão distante já da morte heroica, redentora mesmo, da "Homenagem a Cara de Cavalo", de Hélio Oiticica, fala de uma morte mais triste, anônima, massificada e comum (embora, nos dois casos, sempre violenta). Os 111 mortos, de quem apenas sabemos os nomes, têm a carne de ninguém de que é feita a morte entre nós. Espero que este trabalho ajude a formalizar, livremente mas com nitidez, tamanha tristeza. (1997, p. 177, p. 3).
}

\section{Conclusão}

Em Cujo, Nuno registra as vozes alternadas de suas linguagens. A voz narrativa do que des-cobre singularidade poética de cada "coisa" e a voz de artista plástico que discorre, de modo fragmentado, sobre seu processo artístico desenvolvido no ateliê. Nuno, em Cujo, registra a recorrência das técnicas e dos procedimentos que combina de modo inusitado para a transformação das matérias; na mesma medida que se propõe a mimetizar a corporeidade das materialidades com as quais convive cotidianamente.

Os fragmentos e aforismos de Cujo se distanciam de um discurso prolixo porque, de fato, correspondem à linguagem visual também assinalada por embates e contrastes matéricos que a caracterizam. Na literatura, os fragmentos das palavras rebatem a realidade física da exibição matérica (re)configurada na obra visual de Nuno.

Considera-se a ideia de tradução evidenciada entre a obra visual Vidrotexto 1 (na capa) e o respectivo texto literário de Cujo. A combinação matérica inusitada na obra Vidrotexto 1 vai ao encontro da significativa inclusão da palavra na obra deste artista corpóreo, que utiliza a linguagem textual como um registro do seu incansável processo criativo na investigação da palavra como tradução - a palavra unívoca, na obra visual, é neutralizada no seu aspecto estritamente verbal. O literário se torna flexível e dialoga com um certo minimalismo da obra artística (como profere Didi-Huberman, 1988), aproximando as linguagens e unificando a densidade poética no proferir o mundo.

Portanto, neste estudo constatamos como Nuno Ramos, através do diálogo entre as formulações apresentadas na produção visual e as correspondências nas obras literárias, promove a aproximação entre a linguagem verbal e a linguagem plástica (e vice-versa), na tentativa de uma dialética voltada para um comentário do mundo. 


\section{Referências Bibliográficas}

DIAS, A. Nuno Ramos e suas torres de babel: o criador como tradutor. In: ALENCAR, A. et. al. Tradução literária: a vertigem do próximo. Rio de Janeiro: Beco do Azougue, 2011, p. 23.

DIDI-HUBERMAN, G. O que vemos, o que nos olha. São Paulo: Ed. 34, 1998.

JAKOBSON, R. Linguística e comunicação. São Paulo: Cultrix, 1969.

LIMA, M. R. Eduardo Frota, Nuno Ramos: palavra e modos de uso. Revista Poiésis, Rio de Janeiro, dez. 2011, n 18, p. 27-34.

MAMMI, L.; TASSINARI, A.; NAVES, R. Nuno Ramos. São Paulo: Ática, 1997.

NUNES, T. T. Corpo e alegoria: João Gilberto Noll - Walter Benjamin. Niterói: EDUFF, 2011.

OLIVEIRA, E. J. Nuno Ramos. Literatura, um boneco de piche. Suplemento Literário de Minas Gerais, Belo Horizonte, Nov. 2009, № 1.326. Disponível em: <www.nunoramos. com.br>. Acesso em: 18 dez. 2013.

RAMOS, N. Cujo. Rio de Janeiro: Editora 34, 1993 (2ª ed. 2011). 